\title{
Ecology of testate amoebae (Protists) in Sphagnum peatlands of eastern Poland: Vertical micro-distribution and species assemblages in relation to environmental parameters
}

\author{
Tomasz Mieczan* \\ Department of Hydrobiology, University of Life Sciences, Dobrzańskiego 37, Lublin 20-262, Poland
}

Received 17 July 2008; Accepted 16 December 2008

\begin{abstract}
The testate amoebae communities living among different species of mosses in Sphagnum peatlands in eastern Poland were studied. Sampling was done on a monthly basis from April to November 2005-2007. To assess the importance of the vertical distribution of testate amoebae within the mosses, each sample was cut into two parts: the upper living part $(1-5 \mathrm{~cm})$ and the lower dead part $(5-10 \mathrm{~cm})$. The highest species richness occurred in hollows dominated by Sphagnum angustifolium, Sphagnum flexuosum and Sphagnum palustre. Lower numbers of taxa were observed in hummocks dominated by Sphagnum magellanicum, Polytrichum strictum and Polytrichum commune. There was a distinct horizontal micro-zonation of the abundance of testate amoebae occurring among Sphagnum mosses, but only a small difference ascertained among Polytrichum. The number of testate amoebae was significantly greater in the deeper samples. The results demonstrated that depth to water table, $\mathrm{pH}$ and total organic carbon can strongly regulate the abundance and taxonomic composition of testate amoebae.
\end{abstract}

Key words: Biodiversity / classification / micro-distribution / protists / wetlands

\section{Introduction}

Testate amoebae (Protozoa: Rhizopoda) are common inhabitants of moist soils, lakes and peatlands (Tolonen et al., 1992). They produce a decay-resistant test, or shell, that protects the cell from desiccation. The shell may be proteinaceous, siliceous, or calcareous and may incorporate extraneous materials such as mineral grains, fungal hyphae and diatoms (Odgen and Hedley, 1980). The morphology of tests is usually unique, allowing specieslevel identification. In addition, testate amoebae produce shells which are well preserved in peat and allow paleoenvironmental reconstruction (Mitchell et al., 2000a). Their well-defined ecological preferences in relation to important ecological variables in peatlands have made them useful in ecological studies (Charman, 1997). Testate amoebae are excellent indicators of calcite precipitation in lakes (Casper and Schönborn, 1985) and heavy metal pollutants in peatlands (Nguyen-Viet et al., 2007). Previous studies have shown that the abundance of each taxon, and hence the structure of communities, are controlled by a set of environmental variables. Moisture conditions have often been identified as the most important factor controlling

\footnotetext{
*Corresponding author: tomasz .mieczan@up. lublin.pl
}

testate amoebae community composition in peatlands (Charman and Warner, 1997; Mitchell et al., 2000a). Numerous ecological studies dealing with the responses of recent species to the water level gradient in Sphagnum peatlands provide a good basis for the usage of testate amoebae as indicators of past hydrological changes, and also as recent indicators of hydrological changes during restoration (Buttler et al., 1996; Booth, 2002; Kishaba and Mitchell, 2005; Opravilová and Hájek, 2006). According to Bobrov et al. (1999), Mitchell et al. (2000b), Booth (2002) and Mieczan (2007a, 2007b) the composition of testate amoebae communities is primarily controlled by the moisture regime, and to a lesser extent by $\mathrm{pH}$. Opravilová and Hájek (2006) found that nutrient status is a secondary control on amoebae communities. Even temperature can co-determine the distribution pattern of the testacean fauna (Schönborn, 1962). Testate amoebae require a minimum temperature at a specific time of the year to reproduce successfully. In addition, factors such as light, oxygen and food availability may also affect testate amoebae communities (Charman et al., 2000). The ecology of most species is still rather poorly known although there have been a number of recent studies in several regions of the world, including New Zealand (Charman, 2001), north-western Poland (Lamentowicz and Mitchell, 2005), 
Alaska (Payne et al., 2006), and in France (Nguyen-Viet et al., 2007). Several authors have studied the vertical micro-distribution of testate amoebae in peatlands. One of the main observations has been that mixotrophic species preferentially colonize the uppermost part of mosses, where their endo-symbionts can photosynthesize, whereas heterotrophic species are found in the lower part of the mosses (Heal, 1962; Mitchell and Gilbert, 2004). Microdistribution of testate amoebae taxa has been observed along the Sphagnum stem, and this spatial variation has been attributed primarily to gradients of light, temperature, oxygen and food (Meisterfeld, 1977). Vertical microdistribution is also a gradient from mostly live testate amoebae in the aerobic, upper portions and mostly empty test in the more anaerobic, lower portions (Booth, 2002). However the vertical micro-distribution of testate amobae has not been studied with respect to individual moss species. These comparisons can provide insights into the ecology of testate amoebae, and may guide the collection of more representative calibration datasets. However, information concerning the relationships between environmental factors and the seasonal occurrence of testate amoebae is almost completely lacking (but see Heal, 1964; Warner et al., 2007). More needs to be learned about the sensitivity of these microorganisms to change (either human-induced or natural), if testate amoebae are to be used as bioindicators of human pollution and environmental disturbance. Whilst important gaps remain in our understanding of the relationships between testate amoebae and seasonal changes (Warner et al., 2007), the aims of this study were (i) to examine the community structure and vertical micro-distribution of testate amoebae in Sphagnum-dominated peatlands; (ii) to improve our understanding of factors affecting the distribution of moss testate amoebae communities; and (iii) to analyze the seasonal changes of testate amoebae communities.

\section{Materials and methods}

\section{Study site}

The study was performed in peatlands located in the western part of the Polesie Lubelskie (Eastern Poland, $\left.51^{\circ} \mathrm{N}, 23^{\circ} \mathrm{E}\right)$. Its borders encompass the most precious parts of Poleski National Park, including lakes and floodplains, as well as swamps and peatlands, which survived until now in relatively unaltered conditions. It is one of the most natural region in Poland that was not covered by the last glaciation. The mean air monthly temperatures of January and July were $-4.1^{\circ} \mathrm{C}$ and $17.9^{\circ} \mathrm{C}$, respectively. Mean annual rainfall is $c a .551 \mathrm{~mm}$. The raised and transitional bogs selected for this study were considered to be representative of the bogs of the region and contained a broad diversity of habitats. All of these sites are oligotrophic and are dominated by peat mosses (Sphagnum spp.) and vascular plants characteristic of nutrient-poor peatlands. The vegetation of peatlands is characterized by the presence of a number of rare species, such as
Scheuchzeria palustris L., Drosera anglica Huds., Drosera intermedia Hayne, Salix myrtilloides L. and Salix lapponum L. The vegetation is also dominated by graminoids such as Eriophorum vaginatum (L.), Carex acutiformis Ehrhart, Carex gracilis Curt. Mosses are present, but less abundant. Bryophytes include species such as Sphagnum angustifolium (C.C.O. Jensen ex Russow), Sphagnum cuspidatum Ehrh. ex Hoffm., Sphagnum flexuosum Dozy and Molk., Sphagnum magellanicum Bird., Polytrichum strictum Menzies ex Brid., and Polytrichum commune Hedw. (Table 1).

\section{Field sampling and laboratory analyses}

Samples for testate amoebae analysis were collected from five peatlands. The micro-sites sampled in this study include hummocks, lawn and hollows. Eight samples were collected from the studied peatlands once a month from April to November from 2005 to 2007. A total of 160 samples were taken. Each sample was packed into a cylindrical plastic container $(10 \mathrm{~cm}$ in diameter $)$, which was driven into the moss carpet and cut with the knife. To assess the importance of the vertical distribution of testate amoebae within the mosses, each sample was cut into two sub-samples: the living green part and the dead brown part. All samples were storted in a cooler and transported within one day to the laboratory. Testate amoebae were isolated from moss samples using standard methods (Hendon and Charman, 1997), by boiling and sieving the samples through nested sieves of $250 \mu \mathrm{m}$ and $10 \mu \mathrm{m}$ plankton net. The sample was mounted in glycerol, and slides were scanned until a total of at least 150 testate amoebae were identified and counted at $\times 500$ magnification. The relative abundance of each taxon was calculated as a percentage of total individuals counted. The abundance of microorganisms was expressed as number of individuals per gram of plant material (ind.g ${ }^{-1}$ ). Specimens were identified to the lowest possible taxonomic level. The following literature was used for species/ ecophenotypes identification: Odgen and Hedley (1980), Charman et al. (2000) and Clarke (2003). Various environmental variables (e.g., depth to water table-DWT, $\mathrm{pH}$ and conductivity) were measured at each sampling site on the day of sample collection. Depth to water table was measured in the hole where the sample was removed after a period of 5-10 min. Depth of water table was measured within a centimetre measure. Zero level was marked by the top parts of the peatmosses. Temperature, $\mathrm{pH}$ and conductivity were determined using a JENWAY 3405 electrode. Total organic carbon (TOC) was determined using the PASTEL UV and the remaining environmental data $\left(\mathrm{N}-\mathrm{NO}_{3}, \mathrm{P}_{-} \mathrm{PO}_{4}, \mathrm{P}_{\text {tot }}\right)$ were analysed in the laboratory (Hermanowicz et al., 1976).

\section{Data analyses}

Diversity analysis (Shannon Wiener diversity index, $\log _{10}$-based) was performed using the Multivariate 
Table 1. Main characteristics of the five peatland sites sampled in this study.

\begin{tabular}{|c|c|c|c|c|}
\hline Site name & Location & $\begin{array}{l}\text { Area } \\
\text { (ha) }\end{array}$ & Moss species sampled & Habitat and dominant vascular plants \\
\hline$\overline{\text { Blizionki/Lejno (B) }}$ & $\begin{array}{c}51^{\circ} 25.093^{\prime} \mathrm{N} \\
23^{\circ} 4.124^{\prime} \mathrm{E}\end{array}$ & 71.73 & $\begin{array}{l}\text { Sphagnum magellanicum Bird., } \\
\text { Sphagnum flexuosum Dozy \& Molk., } \\
\text { Polytrichum strictum Menzies ex Brid. }\end{array}$ & $\begin{array}{l}\text { Hummock with Drosera anglica Huds., } \\
\text { Hollow, Sphagnum carpet with Carex } \\
\text { limosa L. }\end{array}$ \\
\hline Durne Bagno (DB) & $\begin{array}{r}51^{\circ} 22.344^{\prime} \mathrm{N}, \\
23^{\circ} 12.303^{\prime} \mathrm{E}\end{array}$ & 213.2 & $\begin{array}{l}\text { Sphagnum angustifolium (C.E.O. Jensen } \\
\text { ex Russow) }\end{array}$ & $\begin{array}{l}\text { Hummock with Ledum palustre L., } \\
\text { Vaccinum uliginosum L., Hollow, } \\
\text { Sphagnum carpet with Carex limosa L. }\end{array}$ \\
\hline Długie (D) & $\begin{array}{r}51^{\circ} 23.044^{\prime} \mathrm{N}, \\
23^{\circ} 11.201^{\prime} \mathrm{E}\end{array}$ & 694.93 & $\begin{array}{l}\text { Sphagnum magellanicum Bird., } \\
\text { Polytrichum strictum Menzies ex Brid., } \\
\text { Polytrichum commune Hedw. }\end{array}$ & $\begin{array}{l}\text { Hummock with Ledum palustre L., } \\
\text { Hollow, Drosera anglica Huds., } \\
\text { Drosera intermedia Hayne, Sphagnum } \\
\text { carpet with Carex limosa L. }\end{array}$ \\
\hline Moszne (M) & $\begin{array}{c}51^{\circ} 23.090^{\prime} \mathrm{N} \\
23^{\circ} 8.122^{\prime} \mathrm{E}\end{array}$ & 205.16 & $\begin{array}{l}\text { Sphagnum flexuosum Dozy \& Molk., } \\
\text { Sphagnum cuspidatum Ehrh. ex Hoffm., } \\
\text { Sphagnum magellanicum Bird., } \\
\text { Sphagnum palustre L., Polytrichum } \\
\text { strictum Menzies ex Brid., Polytrichum } \\
\text { commune Hedw. }\end{array}$ & $\begin{array}{l}\text { Hummock with Ledum palustre L., } \\
\text { Andromeda polifolia L., Drosera } \\
\text { anglica Huds., Drosera intermedia } \\
\text { Hayne, Hollow, Sphagnum carpet } \\
\text { with Eriophorum vaginatum L., } \\
\text { Carex acutiformis Ehrhart., } \\
\text { Carex gracilis Curt. }\end{array}$ \\
\hline $\begin{array}{l}\text { Krugłe Bagno/ } \\
\text { Jelino }(\mathrm{J})\end{array}$ & $\begin{array}{c}51^{\circ} 24.099^{\prime} \mathrm{N} \\
23^{\circ} 9.116^{\prime} \mathrm{E}\end{array}$ & 19.7 & $\begin{array}{l}\text { Sphagnum magellanicum Bird (C.E.O. } \\
\text { Jensen ex Russow), Sphagnum } \\
\text { angustifolium (C.E.O. Jensen ex } \\
\text { Russow) }\end{array}$ & $\begin{array}{l}\text { Hummock with Ledum palustre L., } \\
\text { Hollow, Sphagnum carpet with } \\
\text { Eriophorum vaginatum L. }\end{array}$ \\
\hline
\end{tabular}

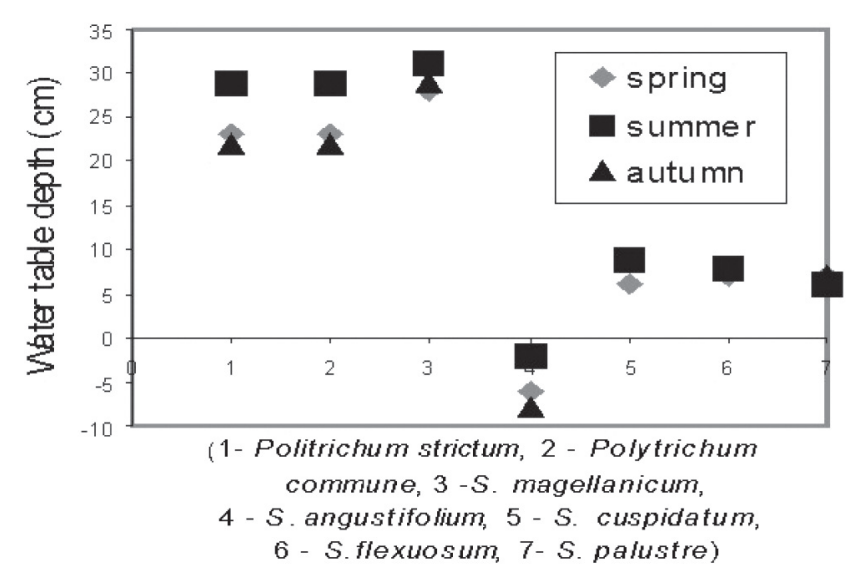

Fig. 1. Seasonal patterns of the depth to water table (DWT) in the studied peatlands (average values for period AprilNovember 2005-2007).

Statistical Package MVSP (Kovach Computering Services; MVSP, 2002). Principal component analyses (PCA) was used to analyze relationships among the continuous environmental variables. Detrended correspondence analysis (DCA), which only uses species data to constrain the ordination (indirect gradient analysis), was used to analyze species assemblage differences between lower and upper assemblages. To examine the relationship between the community structure of testate amoebae and environmental parameters, a Canonical correspondence analysis (CCA) was applied to the species data using MVSP (2002). Logarithmic transformation $[\ln (\mathrm{x}+1)]$ was performed on species data to normalize the distribution. A Monte Carlo test was used to test the significance of each axis. All tests were done using 999 permutations and significance threshold of $P<0.05$. On the resultant plot, the arrows representing the physico-chemical variables indicate the direction of maximum change of that variable, and the length of each arrow is proportional to the rate of change.

\section{Results}

Depth to the water table fluctuated during the year, and ranged from -8 to $32 \mathrm{~cm}$ (Fig. 1). Water $\mathrm{pH}$ fluctuated from 2 to 4 . In turn, conductivity was significantly differentiated, attaining $30 \mu \mathrm{S} . \mathrm{cm}^{-1}$ to $125.5 \mu \mathrm{S} . \mathrm{cm}^{-1}$. The highest conductivity occurred in summer, but was lower in spring or autumn. In all peatlands examined, water temperature reached its highest value in summer (14.3$18.3^{\circ} \mathrm{C}$ ), and decreased in autumn $\left(1.3-2.3^{\circ} \mathrm{C}\right)$. The concentration of total organic carbon fluctuated be-

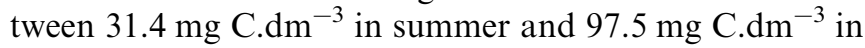
autumn. Nutrients reached their highest values at high $\mathrm{pH}$ micro-sites; the concentration of nutrients were the highest during the spring and autumn periods, and considerably lower in summer. Only Lejno peatlands had a higher concentration of nutrients in summer (Table 2).

A total of 45 testate amoebae taxa were identified (Table 3). The highest numbers of testate amoebae taxa (28-43 taxa) occurred in hollows dominated by Sphagnum angustifolium, Sphagnum cuspidatum, Sphagnum flexuosum and Sphagnum palustre. Lower numbers of taxa (5-15) 
Table 2. Physical and chemical characteristics of water in the studied peatlands (average values for the period April-November 2005-2007); * spring - average values from period April-June, summer - average values from period July-August, autumn - average values from period September-November. Temp. = water temperature, Conduct. $=$ conductivity, $\mathrm{P}_{\text {tot }}=$ total phosphorus, TOC $=$ total organic carbon.

\begin{tabular}{|c|c|c|c|c|c|c|c|c|}
\hline Site name & Season* & $\mathrm{pH}$ & $\begin{array}{l}\text { Temp. } \\
\left({ }^{\circ} \mathrm{C}\right)\end{array}$ & $\begin{array}{l}\text { Conduct. } \\
\left(\mu \mathrm{S} . \mathrm{cm}^{-1}\right)\end{array}$ & $\begin{array}{c}\mathrm{N}-\mathrm{NO}_{3} \\
\left(\mathrm{mg} \mathrm{NO} \mathrm{NO}_{3} \cdot \mathrm{dm}^{-3}\right)\end{array}$ & $\begin{array}{c}\mathrm{PO}_{4}^{3-} \\
\left(\mathrm{mg} \mathrm{PO}_{4} \cdot \mathrm{dm}^{-3}\right)\end{array}$ & $\begin{array}{c}\mathrm{P}_{\text {tot }} \\
\left(\mathrm{mg} \mathrm{P} \cdot \mathrm{dm}^{-3}\right)\end{array}$ & 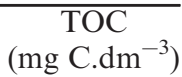 \\
\hline \multirow[t]{3}{*}{ Blizionki/Lejno } & spring & 3.8 & 8.5 & 45.4 & 0.398 & 0.014 & 0.186 & 65.2 \\
\hline & summer & 3.16 & 17.5 & 124.45 & 0.566 & 0.077 & 0.116 & 76.5 \\
\hline & autumn & 3.5 & 1.3 & 85.3 & 0.273 & 0.042 & 0.557 & 97.5 \\
\hline \multirow[t]{3}{*}{ Durne Bagno } & spring & 4.3 & 7.6 & 108.1 & 1.366 & 0.262 & 0.672 & 50.25 \\
\hline & summer & 5.64 & 17.1 & 125.5 & 1.338 & 0.089 & 0.216 & 39.2 \\
\hline & autumn & 3.71 & 2.3 & 85.5 & 0.922 & 0.324 & 0.749 & 58.2 \\
\hline \multirow[t]{3}{*}{ Długie } & spring & 3.2 & 7.3 & 39.8 & 0.600 & 0.100 & 0.236 & 55.2 \\
\hline & summer & 3.2 & 17.3 & 45.1 & 0.299 & 0.288 & 0.320 & 66.9 \\
\hline & autumn & 3.4 & 2.1 & 45.3 & 0.662 & 0.122 & 0.365 & 66.2 \\
\hline \multirow[t]{3}{*}{ Moszne } & spring & 3.3 & 7.9 & 50.53 & 0.583 & 0.081 & 0.404 & 80.5 \\
\hline & summer & 2.3 & 14.3 & 75.36 & 0.647 & 0.123 & 0.197 & 74.0 \\
\hline & autumn & 3.9 & 2.2 & 51.4 & 0.259 & 0.101 & 0.358 & 82.9 \\
\hline Krugłe & spring & 4.02 & 8.2 & 30.35 & 0.445 & 0.046 & 0.134 & 41.8 \\
\hline \multirow[t]{2}{*}{ Bagno/Jelino } & summer & 4.4 & 18.3 & 39.5 & 0.221 & 0.048 & 0.099 & 31.4 \\
\hline & autumn & 4.1 & 1.3 & 29.5 & 0.378 & 0.08 & 0.402 & 42.75 \\
\hline
\end{tabular}

were observed in hummocks dominated by Sphagnum magellanicum, Polytrichum strictum and Polytrichum commune. The most frequent taxa were Assulina muscorum, Arcella discoides type, Hyalosphenia papilio, Hyalosphenia elegans and Archerella flavum. Sixteen testate amoebae taxa had frequencies $<5 \%$. The species distribution pattern also showed a higher variation in acid habitats, from with Hyalosphenia papilio in wet habitats to Assulina muscorum assemblages in the drier microhabitats. The data set for statistical analyses was composed of 160 samples, 40 taxa, and 8 environmental variables. Five minor (less abundant) taxa were omitted in the statistical analyses. The first and second axes captured $53 \%$ of the total variation of species data in the PCA. Sampling sites from lawn and hollows were clearly separated along the first axis that represented $42 \%$ of the total species variation. This axis was closely correlated with DWT and $\mathrm{pH}$ (Fig. 2). The DCA showed that species composition of testate amoebae differed between the living green part $(1-5 \mathrm{~cm})$ and the dead brown part $(5-10 \mathrm{~cm})$. The first axis had the highest percentage variance of species data (18\%). The second axis added $9 \%$ of variance (Fig. 3). The number of testate amoebae taxa increased with depth $(P=0.002)$ (Table 3). Assulina muscorum, Hyalosphenia papilio and Hyalosphenia elegans were relatively more abundant in the uppermost, photosynthetic part of the mosses, and decreased in relative abundance with depth. Arcella discoides and Archerella flavum were relatively more abundant in the deeper samples. The number of taxa and their abundances differed between Sphagnum angustifolium, Sphagnum cuspidatum, Sphagnum flexuosum and Sphagnum palustre; however, only a slight difference was ascertained between the abundance of testate amoebae among Polytrichum strictum, Polytrichum commune and
Sphagnum magellanicum. In the micro-environment dominated by Polytrichum, in the living green part and the dead brown part, Assulina muscorum occurred in the highest numbers (Table 3 ). The diversity analysis revealed a mean Shannon-Wiener diversity index $(\mathrm{H})$ of 2.45. The highest diversity was measured in Sphagnum cuspidatum $(\mathrm{H}=2.8)$, and the lowest diversity was observed in Polytrichum strictum $(\mathrm{H}=0.65)$. The species diversity, minimal in the uppermost 5-cm layer of sphagnum moss (mean Shannon index $=1.0$ ), remained at approximately the same level in the deeper layers (2.3-2.8). The species richness alone differed significantly in the uppermost and lowermost layers (Mann-Whitney test with Bonferroni correction for multiple comparisons; $P<0.05$ ). The total density of testate amoebae varied between 9 and 23.000 ind. $\mathrm{g}^{-1}$ of moss in the samples. The greatest abundance of testate amoebae was ascertained at the micro-sites dominated by Sphagnum flexuosum ( > 23000 ind. $\mathrm{g}^{-1}$ ), and the lowest was observed at sites dominated by Polytrichum (9-12 ind.g $\left.{ }^{-1}\right)$. The ordination also separated the sampling habitats quite well. Hummock sites dominated by Sphagnum magellanicum, Polytrichum commune and Polytrichum strictum mostly had high scores on the first axis. Hollows and lawn sites colonized by Sphagnum angustifolium, Sphagnum cuspidatum, Sphagnum flexuosum and Sphagnum palustre were negatively correlated with the first axis (Fig. 4). In the CCA of testate amoebae data, four environmental variables were significant: DWT, $\mathrm{pH}$, TOC and $\mathrm{P}_{\text {tot }}$. Together, these variables explained $44 \%$ of the variation in the species data. Water table depth and TOC were correlated positively with the first axis, whereas $\mathrm{pH}$ and $\mathrm{P}_{\text {tot }}$ were correlated with the second axis. Water table depth and TOC appeared as dominant controls on the distribution patterns in both the upper and lower assemblages, 
Table 3. Taxonomic composition and taxon frequency (\% of samples) of the testate amoebae found in Sphagnum-dominated peatlands; S. ang. - Sphagnum angustifolium, S. cusp. - Sphagnum cuspidatum, S. flex. - Sphagnum flexuosum, S. mag. - Sphagnum magellanicum, S. pal. - Sphagnum palustre, P. str. - Polytrichum strictum, P. comm. - Polytrichum commune, U - upper assemblages 0-5 cm, L- lower assemblages 5-10 cm. Taxonomy follows Charman et al. (2000).

\begin{tabular}{|c|c|c|c|c|c|c|c|c|c|c|c|c|c|c|c|}
\hline \multirow[b]{3}{*}{ Taxon } & \multirow{3}{*}{$\begin{array}{c}\text { Species } \\
\text { abbreviation }\end{array}$} & \multicolumn{14}{|c|}{ Moss species } \\
\hline & & \multicolumn{2}{|c|}{ S. ang. } & \multicolumn{2}{|c|}{ S. cusp. } & \multicolumn{2}{|c|}{ S. flex. } & \multicolumn{2}{|c|}{ S. mag. } & \multicolumn{2}{|c|}{ S.pal. } & \multicolumn{2}{|c|}{ P. str. } & \multicolumn{2}{|c|}{ P. comm. } \\
\hline & & $\overline{\mathrm{U}}$ & $\overline{\mathrm{L}}$ & $\mathrm{U}$ & $\mathrm{L}$ & $\overline{\mathrm{U}}$ & $\mathrm{L}$ & $\mathrm{U}$ & $\mathrm{L}$ & $\overline{\mathrm{U}}$ & $\overline{\mathrm{L}}$ & $\overline{\mathrm{U}}$ & $\mathrm{L}$ & $\mathrm{U}$ & $\mathrm{L}$ \\
\hline $\begin{array}{l}\text { Amphitrema wrightianum } \\
\text { (Archer, 1877) }\end{array}$ & Amph wr & 15 & 30 & 18 & 15 & 18 & 15 & - & - & 8 & 12 & - & - & - & - \\
\hline Arcella catinus type (Penard, 1980) & Arc cat & - & 2 & - & - & - & 2 & - & - & - & - & - & - & - & - \\
\hline Arcella disoides type (Ehrenberg, 1843) & Arc dis & 49 & 78 & 46 & 73 & 46 & 84 & - & - & 23 & 81 & - & - & - & - \\
\hline Arcella sp. & Arc sp & 1 & 8 & 1 & 8 & 1 & 13 & - & - & 1 & 8 & - & - & - & - \\
\hline Arcella vulgaris (Ehrenberg, 1830) & Arc vul & 18 & 31 & 4 & 56 & 4 & 56 & - & 6 & 9 & 65 & - & - & - & - \\
\hline Archerella flavum (Archer, 1877) & Arch fl & 45 & 69 & 33 & 59 & 46 & 61 & - & 4 & 33 & 42 & - & - & - & - \\
\hline Assulina muscorum (Greeff, 1888) & Ass musc & 8 & 2 & 5 & 2 & 8 & 2 & 67 & 57 & 8 & 2 & 75 & 72 & 81 & 80 \\
\hline Assulina seminulum (Ehrenberg, 1848) & Ass sem & 2 & 1 & - & - & 1 & 1 & - & - & - & - & - & - & - & - \\
\hline $\begin{array}{l}\text { Centropyxis aculeata type } \\
\text { (Ehrenberg, 1830) }\end{array}$ & Cen ac & 6 & 20 & 7 & 29 & 7 & 31 & 4 & 12 & 7 & 31 & 4 & 4 & 4 & 6 \\
\hline $\begin{array}{l}\text { Centropyxis aerophila } \\
\text { (Deflandre, 1929) }\end{array}$ & Cen ar & - & 3 & - & - & - & - & - & - & - & - & - & - & - & - \\
\hline $\begin{array}{l}\text { Centropyxis platystoma type } \\
\text { (Penard, 1890) }\end{array}$ & Cen pl & - & 3 & - & 3 & - & 4 & - & - & 2 & 1 & - & - & - & - \\
\hline Corythion dubium (Taranek, 1881) & Cor dub & - & 2 & 4 & 7 & 4 & 7 & 4 & 7 & 4 & 6 & - & - & - & - \\
\hline Corythion-Trinema type & Cor-typ & - & 3 & 3 & 3 & 3 & 2 & 3 & 2 & 3 & 2 & 4 & 6 & 4 & 4 \\
\hline $\begin{array}{l}\text { Cryptodifflugia oviformis } \\
\text { (Penard, 1890) }\end{array}$ & Cry ov & - & 2 & - & - & - & - & - & - & - & - & - & - & - & - \\
\hline $\begin{array}{l}\text { Cyclopyxis arcelloides type } \\
\text { (Leidy, 1879) }\end{array}$ & Cycl arc & 2 & 2 & 6 & 5 & 6 & 3 & - & - & - & - & - & - & - & - \\
\hline Cyphoderia ampulla (Ehrenberg, 1840) & Cryp amp & 2 & 2 & 2 & 2 & 2 & 3 & - & - & - & - & - & - & - & - \\
\hline Difflugia elegans (Penard, 1980) & Dif el & - & 4 & 3 & 4 & 1 & 4 & - & - & - & - & - & - & - & - \\
\hline Difflugia globulosa (Dujardin, 1841) & Dif gl & - & 3 & - & 3 & 1 & 1 & - & - & - & - & - & - & - & - \\
\hline Difflugia leidyi (Wailes, 1912) & Dif le & - & 2 & - & 2 & 1 & 2 & - & - & 1 & 2 & - & - & - & - \\
\hline Difflugia sp. & Dif sp & - & 2 & - & 2 & - & 10 & - & 7 & 2 & 6 & - & - & - & - \\
\hline Euglypha ciliata (Ehrenberg, 1848) & Eug cil & - & 4 & 7 & 23 & 4 & 19 & - & 8 & 4 & 19 & - & - & - & - \\
\hline Euglypha compressa (Carter, 1864) & Eug com & - & 2 & 6 & 6 & - & 2 & - & - & - & 2 & - & 8 & 8 & 9 \\
\hline Euglypha rotunda type (Wailes, 1911) & Eug rot & - & 2 & - & - & - & - & 28 & 26 & - & - & 6 & 12 & 9 & 12 \\
\hline Euglypha sp. & Eug sp & - & 2 & - & 2 & 1 & 2 & 9 & 12 & - & - & - & 4 & - & - \\
\hline Euglypha strigosa (Ehrenberg, 1872) & Eug st & - & 3 & - & 3 & - & 3 & - & - & - & 3 & - & 5 & - & 5 \\
\hline $\begin{array}{l}\text { Euglypha tuberculata type } \\
\text { (Dujardin, 1841) }\end{array}$ & Eug tub & - & 2 & 2 & 12 & 2 & 12 & 33 & 31 & 2 & 8 & - & - & - & - \\
\hline Heleopera petricola (Leidy, 1879) & Hel pet & 3 & 3 & 3 & 26 & 5 & 19 & - & - & 9 & 3 & - & - & - & - \\
\hline Heleopera rosea (Penard 1890) & Hel ros & 3 & 3 & 3 & 3 & 3 & 3 & - & - & 3 & 3 & - & - & - & - \\
\hline Heleopera sphagnii (Leidy, 1874) & Hel sph & 3 & 3 & 3 & 3 & 6 & 3 & - & - & 6 & 3 & - & - & - & - \\
\hline Hyalosphenia elegans (Leidy, 1874) & Hel ele & 32 & 30 & 46 & 43 & 63 & 49 & 16 & 9 & 63 & 56 & - & - & - & - \\
\hline Hyalosphenia ovalis (Wailes, 1912) & Hya ov & 15 & 21 & 12 & 11 & 8 & 6 & - & - & 8 & 9 & - & - & - & - \\
\hline Hyalosphenia papilio (Leidy, 1875) & Hya pap & 33 & 28 & 23 & 19 & 25 & 20 & - & - & 34 & 27 & - & - & - & - \\
\hline $\begin{array}{l}\text { Hyalosphenia subflava (Cash and } \\
\text { Hopkinson, 1909) }\end{array}$ & Hya sub & 2 & - & 2 & 2 & - & 2 & - & - & - & 5 & - & - & - & - \\
\hline Nebela bohemica (Taranek, 1881) & Neb boh & 3 & - & 3 & - & 3 & - & - & - & 3 & - & - & - & - & - \\
\hline Nebela carinata (Leidy, 1876) & Neb car & 1 & 1 & 2 & 2 & 1 & 2 & - & - & 1 & 2 & - & - & - & - \\
\hline Nebela collaris (Ehrenberg, 1848) & Neb col & 4 & 1 & 4 & 3 & 4 & 3 & - & - & 3 & 3 & - & - & - & - \\
\hline Nebela flabellulum (Leidy, 1874) & Neb fla & 1 & 1 & 1 & 1 & 1 & 1 & - & - & 1 & 1 & - & - & - & - \\
\hline Nebela griseola type (Penard, 1911) & Neb gris & 4 & 4 & 4 & 4 & 4 & 5 & - & - & - & 5 & - & - & - & - \\
\hline Nebela militaris (Penard, 1890) & Neb mil & 2 & 3 & 4 & 5 & 4 & 5 & 3 & 3 & - & 4 & - & - & - & 3 \\
\hline $\begin{array}{l}\text { Nebela parvula }(\text { Cash and } \\
\text { Hopkinson, 1909) }\end{array}$ & Neb par & 2 & 3 & 2 & 3 & 2 & 3 & - & - & 2 & 3 & - & - & - & - \\
\hline Nebela sp. & Neb sp & - & 1 & - & 1 & - & 1 & - & - & - & 1 & - & - & - & 2 \\
\hline Nebela tincta (Leidy, 1879) & Neb tin & 2 & 1 & 2 & 1 & - & 1 & - & - & - & 1 & - & - & - & - \\
\hline Nebela vitraea type (Penard, 1899) & Neb vit & 1 & 1 & 1 & 1 & - & 1 & 1 & 1 & - & 1 & - & - & - & - \\
\hline Placocista spinosa type (Carter, 1865) & Plac spin & 3 & 18 & 3 & 18 & 4 & 19 & 7 & 8 & 4 & 11 & - & - & - & - \\
\hline Trigonopyxis arcula (Leidy, 1879) & Trig arc & 4 & 2 & 6 & 3 & - & 5 & - & - & - & 5 & - & - & - & - \\
\hline Total species number 45 & & 28 & 43 & 33 & 39 & 32 & 41 & 11 & 15 & 26 & 34 & 4 & 7 & 5 & 8 \\
\hline
\end{tabular}




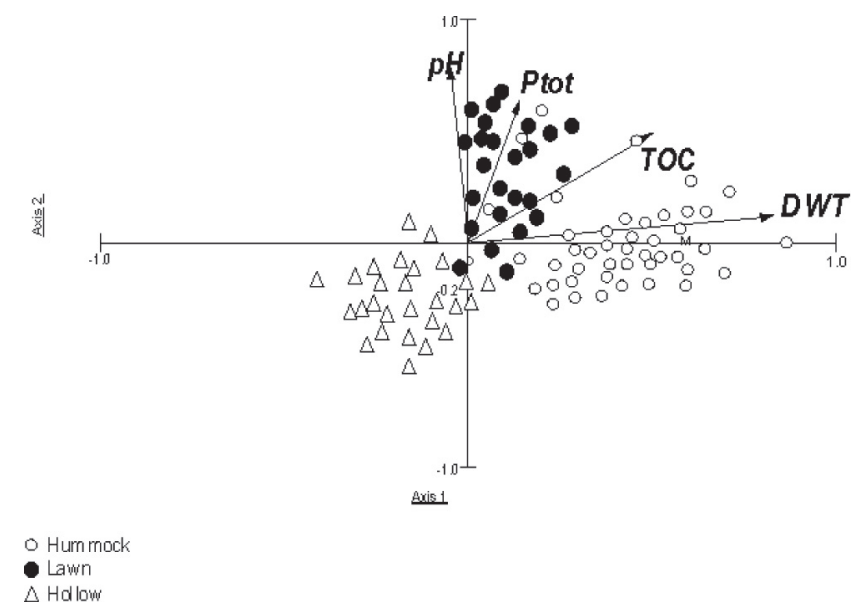

Fig. 2. PCA ordination plot of testate amoebae samples (logtransformed data).

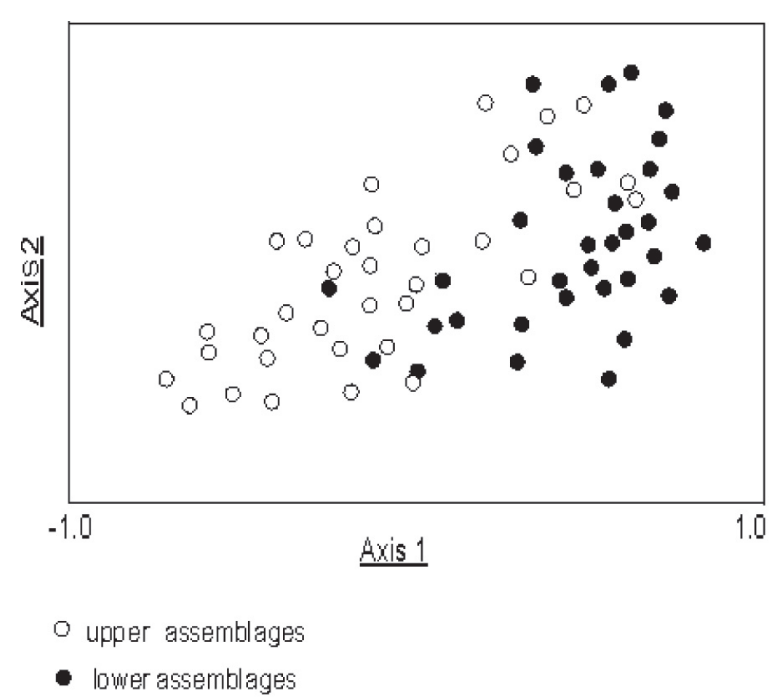

Fig. 3. Sample plot of detrended correspondence analysis (DCA) of testate amoebae data.

and the total variance explained by each CCA was similar. Monte Carlo permutation tests (Ter Braak, 1988) on these variables showed that DWT and concentrations of TOC were significant at $P<0.001$. These two factors captured $23 \%$ of total variation of species data. The $\mathrm{pH}$ and $\mathrm{P}_{\text {tot }}$ played a less significant role. The relationships between each of these parameters and the species ordination were significant $(P<0.01)$ and explained $21 \%$ of the variation. The CCA ordination showed that the species could be separated into three groups. The first group included species associated with high DWT and TOC values (i.e., dry conditions), and with low pH (Assulina muscorum, Euglypha rotunda type, Euglypha tuberculata type, Nebela tincta, Corythion-Trinema type). The second group included species that were associated with low DWT values (wet conditions) and low $\mathrm{pH}$ (Hyalosphenia elegans, Archerella flavum, A. wrightianum, Nebela carinata, Arcella discoides). The third group included species associated

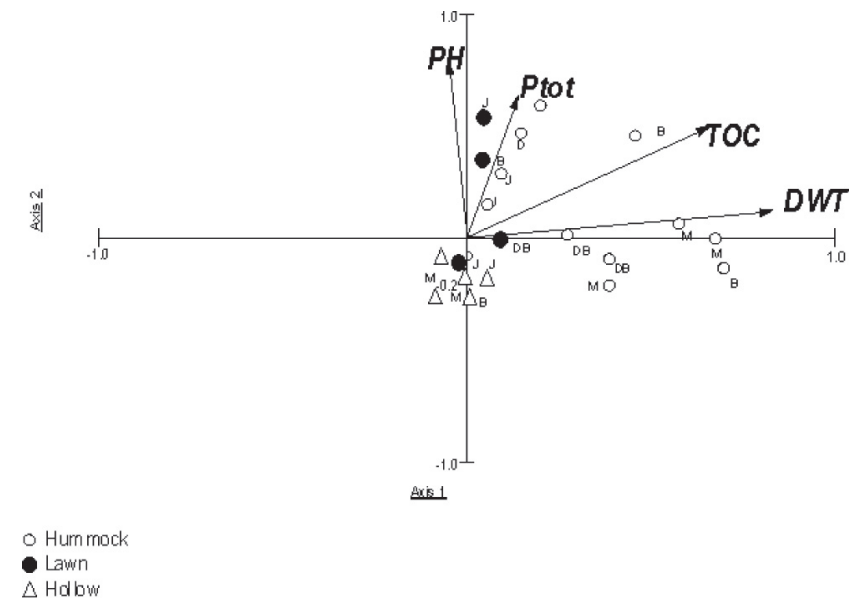

Fig. 4. Bi-plots of canonical correspondence analysis (CCA) of testate amoebae data from Sphagnum-dominated peatlands with representation of samples and environmental variables. Samples data were log-transformed, and rare species were downweighted.

with high $\mathrm{pH}$ conditions, mid-range DWT and higher concentrations of $\mathrm{P}_{\text {tot }}$ (Centropyxis aculeata, C. aerophila, Nebela bohemica) (Figs. 5A and 5B). Analysis of testate amoebae data and environmental variables revealed seasonal changes in environmental conditions and species composition. The eigenvalues of the first and second axis were 0.041 and 0.033 , respectively. These two axes captured $12 \%$ of the total variation of species data. Samples in summer and autumn clustered together, but spring samples were plotted separately in the ordination diagram. Depth of the water table, $\mathrm{pH}, \mathrm{TOC}, \mathrm{P}_{\mathrm{tot}}$ spring and autumn had significant regression coefficients. Differences in testate amoebae were primarily explained by microzonation, which is closely related to wetness. Water chemistry and season were secondary factors to explain testate amoebae distribution (Fig. 6).

\section{Discussion}

The similarity of testate amoeba assemblages between our own study sites, and with other European sites (Jauhiainen, 2002; Lamentowicz and Mitchell, 2005) is not surprising given the cosmopolitan distribution of many taxa. The highest numbers of taxa occurred in hollows dominated by Sphagnum angustifolium, Sphagnum cuspidatum, Sphagnum flexuosum and Sphagnum palustre. The low diversity of testate amoebae in Polytrichum is probably the consequence of the low moisture in this micro-environment. The number of taxa increased, however, with the drop in $\mathrm{pH}$, and together with the increase in moisture conditions. This compares well to other studies (Booth, 2002; Mazei et al., 2007). Considerable variation in the vertical distance spanned by the upper and lower assemblages existed between microsites, which is probably a result of differences in growth form and species of mosses. The lower assemblages had a significantly higher taxonomic richness than the upper assemblages. 


\section{(A) Upper assemblages}

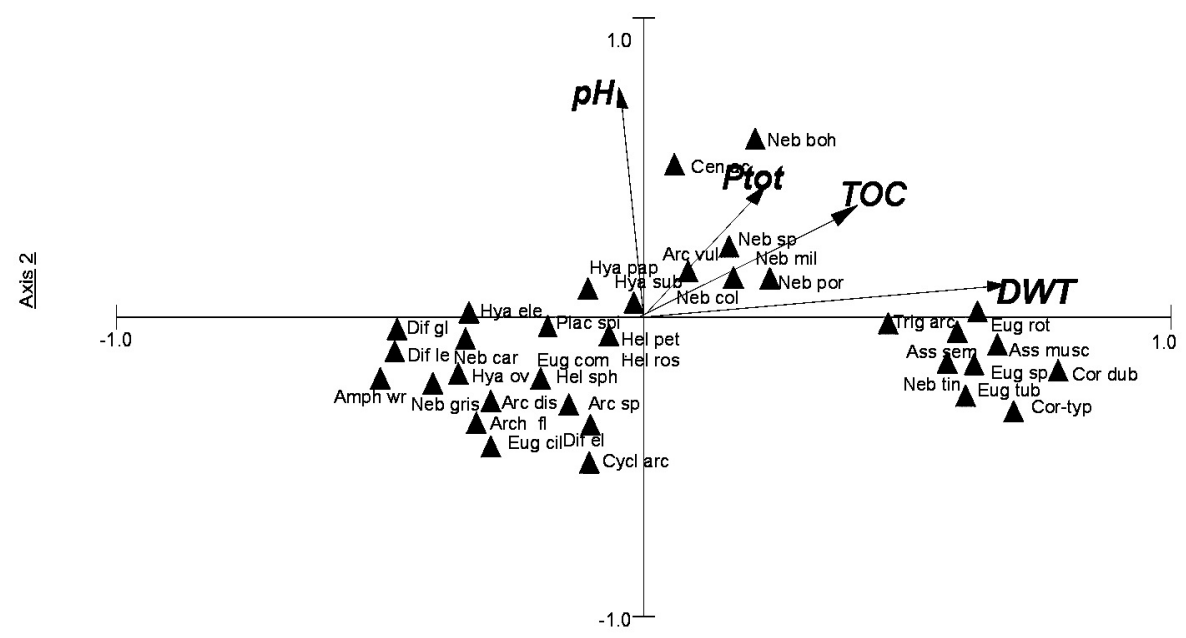

Axis 1

\section{(B) Lower assemblages}

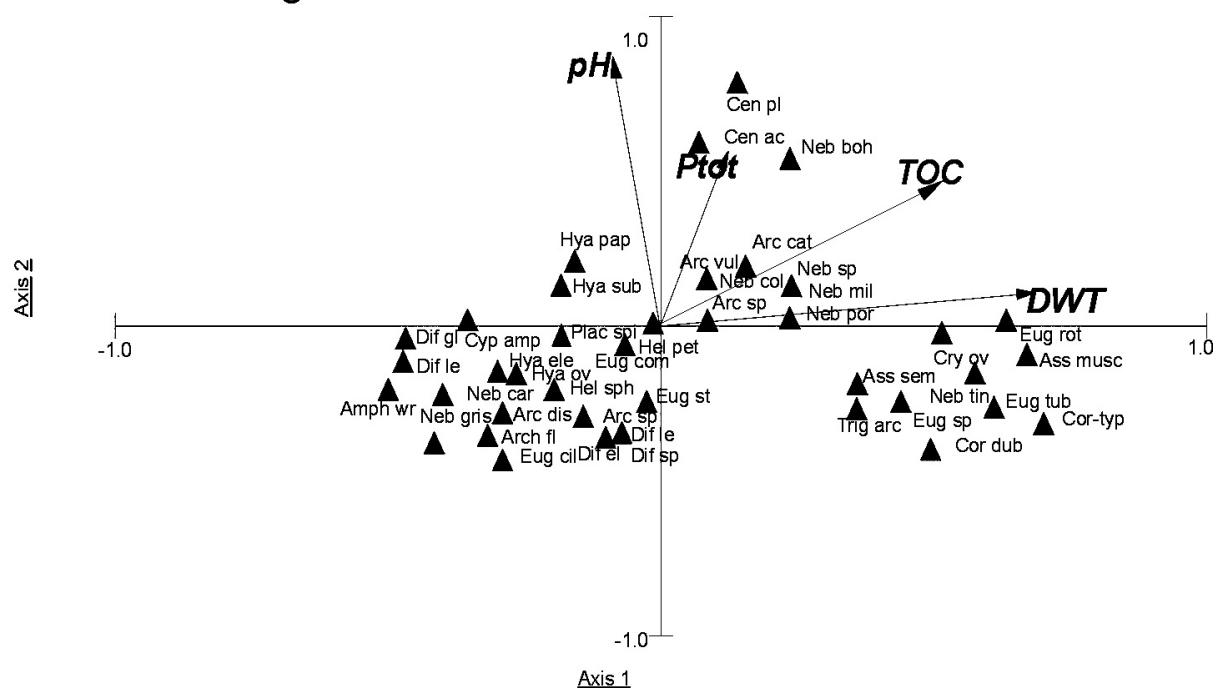

Fig. 5. Bi-plots of canonical correspondence analysis (CCA) of testate amoebae and environmental variables in (A) upper assemblages, and (B) lower assemblages. Abbreviations for testate amoebae are shown in Table 3.

Several factors probably contributed to this pattern. According to Booth (2002) and Mazei et al. (2007), some taxa occur predominantly in the upper portions of the mosses, and these taxa eventually become incorporated into the lower assemblage by vertical transport, and/or growth and senescence of the moss. Likewise, a distinct increase in moisture in the lower parts of the mosses may be the result of the abundance in testate amoebae.

There was a strong relationship between testate amoebae communities and both water table depth and $\mathrm{pH}$. There was also a significant influence of total phosphorus on the occurrence of testate amoebae. In Sphagnum peatlands, testate amoebae communities were related to $\mathrm{NO}_{3}^{-}$ (Mitchell et al., 2000a), and to a combination of physical and chemical variables such as moisture, $\mathrm{pH}$, nitrogen, and dissolved organic carbon (Tolonen et al., 1994; Jauhiainen, 2002). I found that the influence of total phosphorus increased with the increase in $\mathrm{pH}$. In previous research on testate amoebae in relation to the chemical environment, many of the significant explanatory variables were nutrients (Tolonen et al., 1994; Mitchell et al., 2000b). It seems that nutrients have an indirect influence 


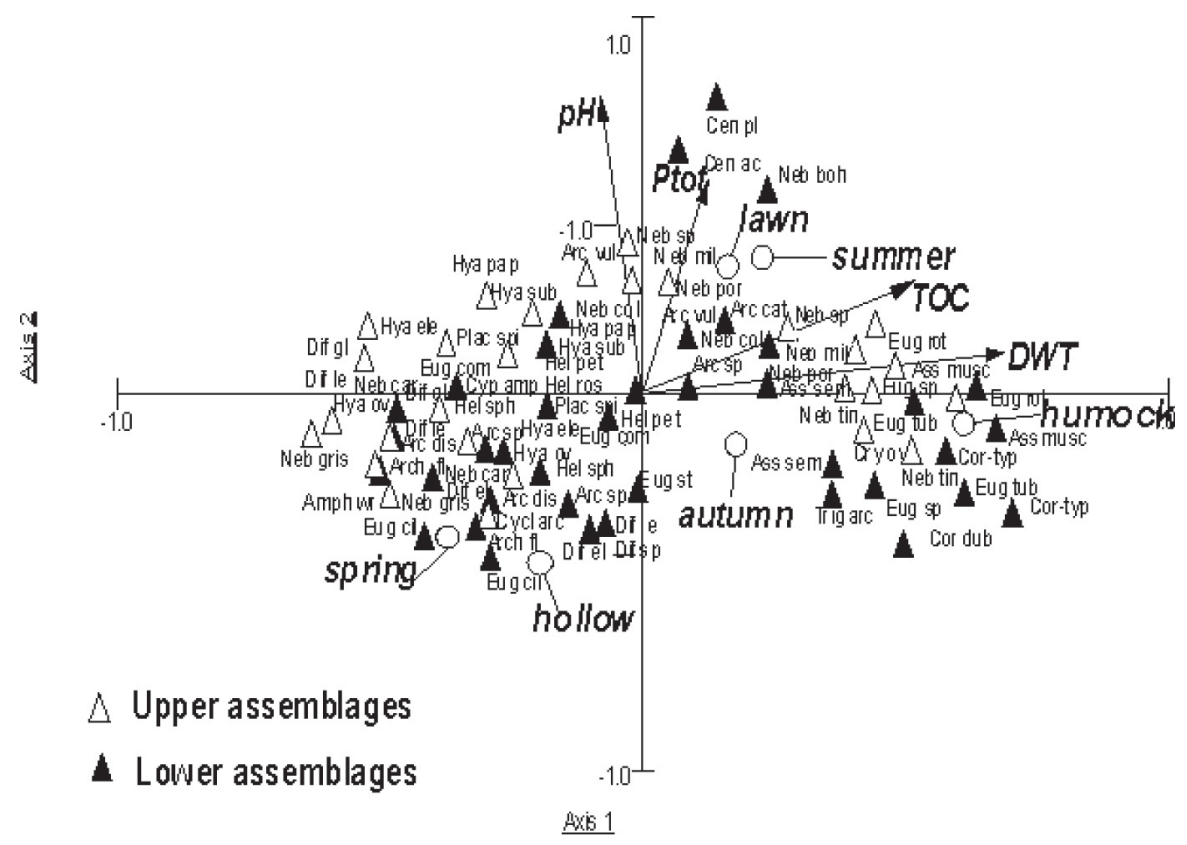

Fig. 6. Bi-plot of canonical correspondence analysis (CCA) of testate amoebae data including all the sampling stations, seasons and environmental variables. Abbreviations for testate amoebae are shown in Table 3.

on the prevalence of testate amoebae through the control food abundance (mainly bacteria, fungi, or protists). The CCA showed that DWT and $\mathrm{pH}$ were dominant factors controlling the distribution patterns of the upper and lower assemblages. These factors, however, showed distinct seasonal changes. During the spring period, those species characteristic of environments with considerable moisture were recorded in high numbers (e.g., Hyalosphenia elegans, Arcella discoides type, Placocista spinosa). These species are typically found in habitats with high soil water content (Gilbert et al., 2000; Warner et al., 2007). In the other seasons, $\mathrm{pH}$ has a significant influence on the occurrence of these micro-organisms. A distinct increase in the number of testate amoebae was also observed by Heal (1964). Likewise, the study carried out by Warner et al. (2007) determined a seasonal change in the testate amoebae assemblages. The present study shows a significant relationship between testate amoebae and type of microenvironment. In hollows dominated by Sphagnum angustifolium, Sphagnum cuspidatum, Sphagnum flexuosum and Sphagnum palustre, amoebae species characteristic of wet conditions (Arcella discoides type, Arcella vulgaris, Amphitrema wightianum and Archerella flavum) were recorded in high numbers, whereas hummocks dominated by Sphagnum magellanicum and Polytrichum strictum were colonized mostly by testate amoebae located at the dry end of the water table gradient (Assulina muscorum, Euglypha rotunda type and Euglypha tuberculata type). Taxa with symbiotic zoochlorellae were more common at the top of the stem, and agglutinate taxa were more common on lower portions of the stem (Meisterfeld, 1977). A vertical micro-distribution in community of testate amoebae was clear among the Sphagnum moss (Sphagnum angustifolium, Sphagnum cuspidatum, Sphagnum flexuosum and Sphagnum palustre). On the other hand, the distribution pattern was blurred in dry environments dominated by Polytrichum strictum, Polytrichum commune and Sphagnum magellanicum.

In summary, the vertical distribution patterns of testate amoebae in this study were similar to those observed in various studies in Europe (Heal, 1962; Buttler et al., 1996). There was a distinct horizontal micro-zonation of testate amoebae occurring among Sphagnum moss, but only a small difference ascertained among Polytrichum. The number of testate amoebae taxa significantly increased in the deeper samples. The results suggested that depth of water table, $\mathrm{pH}$ and total organic carbon can strongly regulate the abundance and taxonomic composition of testate amoebae. The influence of DWT and TOC were particularly clear in the lower parts of the mosses, and the number of testate amoebae was significantly greater in the deeper samples.

Acknowledgements. Thanks to Andrzej Różycki and Katarzyna Pikunas (Poleski National Park) for useful discussion of peatlands and the logistics of fieldwork. I also thank two anonymous reviewers for providing helpful comments on an earlier version of the manuscript.

\section{References}

Bobrov A.B., Charman D.J. and Warner B.G., 1999. Ecology of testate amoebae (Protozoa: Rhizopoda) on peatlands in Western Russia with special attention to niche separation in closely related taxa. Protistology, 150, 125-136.

Booth R.K., 2002. Testate amoebae as paleoindicators of surface-moisture changes on Michigan peatlands: modern ecology and hydrological calibration. J. Paleolimnol., 28, 329-348. 
Buttler A., Warner B.G., Grosvernier P. and Matthey Y., 1996. Vertical patterns of testate amoebae (Protozoa; Rhizopoda) and peat-forming vegetation on cutover bogs in the Jura, Switzerland. New Phytol., 134, 371-382.

Casper S.J. and Schönborn W., 1985. Difflugia limnetica (Levander) Penard (Protozoa: Testacea) as indicator organism of calcite precipitation in Lake Stechlin, GDR. Arch. Protistenkunde, 130, 305-311.

Charman D.J., 1997. Modelling hydrological relationships of testate amoebae (Protozoa: Rhizopoda) on New Zealand peatlands. J. R. Soc. New Zeal., 27, 465-483.

Charman D.J., 2001. Biostratigraphic and paleoenvironmental applications of testate amoebae. Quatern. Sci. Rev., 20, 1753 1764.

Charman D.J. and Warner B.G., 1997. The ecology of testate amoebae (Protozoa: Rhizopoda) in oceanic peatlands in Newfoundland, Canada: modeling hydrological relationships for paleoenvironmental reconstruction. Ecoscience, 4, 555-562.

Charman D.J., Hendon D. and Woodland W., 2000. The identification of testate amoebae (Protozoa: Rhizopoda) in peats, Quaternary Research Technical Guide, 147 p.

Clarke K.J., 2003. Guide to the identification of soil protozoaTeatate Amoebae, Freshwater Biological Association, UK, $40 \mathrm{p}$.

Gilbert D., Francez A.J., Amblard C. and Bourdier G., 2000. Microbial communities at the surface of Sphagnum peatlands: good indicators of Human disturbances? Bull. Ecol., $30,45-52$.

Heal O.W., 1962. The abundance and microdistribution of testate amoebae (Protozoa, Rhizopoda) in Sphagnum. Oikos, 13, 35-47.

Heal O.W., 1964. Observations on the seasonal and spatial distribution of testacea (Protozoa: Rhizopoda) in Sphagnum. J. Anim. Ecol., 33, 395-412.

Hendon D. and Charman D.J., 1997. The preparation of testate amoebae (Protozoa: Rhizopoda): Samples from peat. Holocene, 7, 199-205.

Hermanowicz W., Dożańska W., Dolido J. and Koziorowski B., 1976. Physical and chemical investigation methods of water and sewage, Arkady, Warszawa, 846 p.

Jauhiainen S., 2002. Testacean amoebae in different types of mire following drainage and subsequent restoration. Eur. $J$. Protistol., 38, 59-72.

Kishaba K. and Mitchell E.A.D., 2005. Changes in testate amoebae (Protists) communities in a small raised bog. A 40-year study. Acta Protozool., 44, 1-12.

Lamentowicz M. and Mitchell E.A.D., 2005. The ecology of testate amoebae (Protists) in Sphagnum in north-western Poland in relation to peatland ecology. Microb. Ecol., 50, 48-63.

Mazei Yu.A., Tsyganov A.N. and Bubnova O.A., 2007. Structure of community of testate amoebae in a sphagnum dominated bog in upper sura flow (Middle Volga Territory). Biol. Bull. Russ. Acad. Sci., 34, 382-394.
Meisterfeld R., 1977. Die horizontale und vertikale Verteilung der Testacean (Rhizopoda: Testacea) in Sphagnum. Arch. Hydrobiol., 79, 319-356.

Mieczan T., 2007a. Epiphytic protozoa (Testate amoebae, Ciliates) associated with Sphagnum in peatbogs: relationship to chemical parameters. Pol. J. Ecol., 55, 79-90.

Mieczan T., 2007b. Seasonal patterns of testate amoebae and ciliates in three peatbogs: relationship to bacteria and flagellates (Poleski National Park, Eastern Poland). Ecohydrol. Hydrobiol., 7, 295-305.

Mitchell E.A.D. and Gilbert D., 2004. Vertical micro-distribution and response to nitrogen deposition in testate amoebae in Sphagnum. J. Eukaryot. Microbiol., 51, 480-490.

Mitchell E.A.D., Borcard D., Buttler A., Grosvernier Ph., Gilbert D. and Gobat J.M., 2000a. Horizontal distribution patterns of Testate amoebae (Protozoa) in a Sphagnum magellanicum Carpet. Microb. Ecol., 39, 290-300.

Mitchell E.A.D., Buttler A., Grosvernier Ph., Hydin H., Albinsson C., Greenup A.L., Heijmans M.M.P.D., Hoosbeek M.R. and Saarinen T., 2000b. Relationships among testate amoebae (Protozoa), vegetation and water chemistry in five Sphagnum-dominated peatlands in Europe. New Phytol., 145, 95-106.

MVSP., 2002. Multivariate Statistical Package, Kovach Computering Services.

Nguyen-Viet H., Gilbert D., Mitchell E.A.D., Badot P.M. and Bernard N., 2007. Effects of experimental lead pollution on the microbial communities associated with Sphagnum fallax (Bryophyta). Microb. Ecol., 54, 232-241.

Odgen C.G. and Hedley R.H., 1980. An atlas of freshwater testate amoebae, British Museum of Natural History and Oxford University Press, London and Oxford, UK, 122 p.

Opravilová V. and Hájek M., 2006. The variation of testacean assemblages (Rhizopoda) along the complete base-richness gradient in fens: a case study from the western Carpathians. Acta Protozool., 45, 191-204.

Payne R.J., Kishaba K., Blackford J.J. and Mitchell E.A.D., 2006. Ecology of testate amoebae (Protista) in south-central Alaska peatlands: building transfer-function models for paleoenvironmental studies. Holocene, 3, 403-414.

Schönborn W., 1962. Zur Ökologie der sphagnikolen, bryokolen un terrikolen Testaceen. Limnologica, 1, 231-254.

Ter Braak C.J.F., 1988. CANOCO-FORTRAN program for Canonical Community Ordination (version 2.1), Ithaca, New York: Microcomputer Power. 96.

Tolonen K., Warner B.G. and Vasander H., 1992. Ecology of Testaceans (Protozoa: Rhizopoda) in mires in southern Finland: I. Autecology. Arch. Protistenkunde, 142, 119-138.

Tolonen K., Warner B.G. and Vasander H., 1994. Ecology of Testaceans (Protozoa, Rhizopoda) in mires in southern Finland. 2. Multivariate-analysis. Arch. Protistenkunde, 144, 97-112.

Warner B.G., Asada T. and Quinn N.P., 2007. Seasonal influences on the ecology of testate amoebae (Protozoa) in small Sphagnum peatland in southern Ontario, Canada. Microb. Ecol., 54, 91-100. 